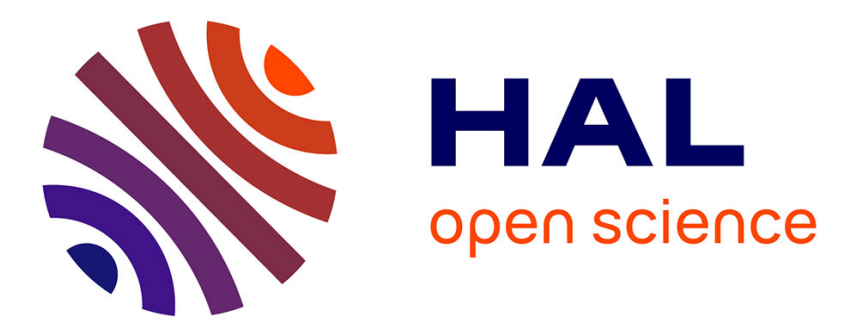

\title{
Cloud Catalog from Mars Orbiter Laser Altimeter / Mars Global Surveyor Data Using Machine Learning Algorithms
}

Vincent Caillé, Anni Määttänen, Aymeric Spiga, Lola Falletti, Gregory A. Neumann

\section{To cite this version:}

Vincent Caillé, Anni Määttänen, Aymeric Spiga, Lola Falletti, Gregory A. Neumann. Cloud Catalog from Mars Orbiter Laser Altimeter / Mars Global Surveyor Data Using Machine Learning Algorithms. EGU General Assembly 2021, Apr 2021, Virtual Meeting, France. pp.EGU21-14672, 10.5194/egusphere-egu21-14672 . insu-03452604

\section{HAL Id: insu-03452604 https://hal-insu.archives-ouvertes.fr/insu-03452604}

Submitted on 27 Nov 2021

HAL is a multi-disciplinary open access archive for the deposit and dissemination of scientific research documents, whether they are published or not. The documents may come from teaching and research institutions in France or abroad, or from public or private research centers.
L'archive ouverte pluridisciplinaire HAL, est destinée au dépôt et à la diffusion de documents scientifiques de niveau recherche, publiés ou non, émanant des établissements d'enseignement et de recherche français ou étrangers, des laboratoires publics ou privés. 
EGU21-14672

https://doi.org/10.5194/egusphere-egu21-14672

EGU General Assembly 2021

(c) Author(s) 2021. This work is distributed under

the Creative Commons Attribution 4.0 License.

\title{
Cloud Catalog from Mars Orbiter Laser Altimeter / Mars Global Surveyor Data Using Machine Learning Algorithms
}

\author{
Vincent Caillé ${ }^{1}$, Anni Määttänen ${ }^{1}$, Aymeric Spiga ${ }^{2}$, Lola Falletti ${ }^{1}$, and Gregory A. Neumann ${ }^{3}$ \\ ${ }^{1}$ Sorbonne Université, UVSQ Paris-Saclay, CNRS, Paris, France \\ ${ }^{2}$ LMD/IPSL, Sorbonne Université, Paris, France - Institut Universitaire de France, France \\ ${ }^{3}$ NASA Goddard Space Flight Center, Greenbelt, Maryland, USA
}

In the development of Mars climate models, modeling clouds is an important challenge, and especially for $\mathrm{CO}_{2}$ clouds. This is due to the complexity of the atmospheric processes involved that may imply rethinking microphysical theories, but also to the scarcity of observations. In the late 90's, Mars Orbiter Laser Altimeter was one of the instruments aboard the Mars Global Surveyor spacecraft. Its first goal was to build a precise map of Mars' topography through laser altimetry but its sensitivity allowed for cloud observations as well. Thus, previous studies (Neumann \& al. 2003 Ivanov \& Muhlemann 2001) have shown that some laser returns were cloud signatures coming from the atmosphere. However, at that time, the huge amount of data was analysed using simple distinction criteria.

We use K-means clustering algorithms to computationally analyse MOLA data. In order to optimise the method, we first determine the best observed parameters to distinguish the different kinds of returns (surface, noise and clouds). The best number of clusters is determined using three independent methods : elbow, silhouette score and gap statistics. The method is tested on a restricted sample ( $10 \%$ of the dataset) and then applied to the full raw dataset. Once that cloud cluster identified, we can plot spatial and temporal distributions of the cloud returns and compare them with previous results.

As mentioned by Neumann \& al. (2003), the product of surface reflectivity and two-way transmissivity of the atmosphere appears as the best parameter discriminating between surface and cloud returns. A unique number of clusters (6) is identified by all three optimisation methods. Among those clusters, one clearly identifies cloud returns, while others represent noise and surface returns. Our methods allows us to identify more clouds than previous studies. Our cloud distribution remains coherent with the ones given in previous studies, showing the viability of our method. We will present a catalog of cloud returns coming from MOLA data. We are now working to separate different kinds of clouds within these returns (absorptive and reflective clouds, $\mathrm{CO}_{2}$ / water clouds, dust ...) using machine learning algorithms and a recent MOLA surface reflectivity map (Heavens \& al. 2016). 